\title{
Przewaga komparatywna krajów Andyjskiego Wspólnego Rynku (CAN) w międzynarodowym handlu towarami z Mercosur
}

Kamil Majcher*

\section{Wstęp}

Andyjski Wspólny Rynek (Comunidad Andina de Naciones - CAN) oficjalnie powstał 26 maja 1969 r. w wyniku podpisania umowy z Kartageny, której sygnatariuszami byli przedstawiciele rządów państw subregionu Ameryki Południowej: Kolumbii (Jorge Valencia Jaramillo), Boliwii (Tomas Guillermo Elio), Chile (Salvador Llunch), Ekwadoru (Jose Pons Vizcaino) oraz Peru (Vicente Cerro Cebrian). Obecnie filarem omawianego podmiotu są cztery państwa członkowskie: Kolumbia, Boliwia, Peru i Ekwador (Compendio de Normas 2014). Prowadzą one ścisłą współpracę gospodarczą z grupą Mercosur, której członkowie (z wyjątkiem Wenezueli) mają status krajów stowarzyszonych z CAN (CAN 2005). Mercosur to regionalne ugrupowanie integracyjne, które powstało na mocy traktatu z Asunción z dnia 26 marca 1991 r. Skupiało ono wówczas cztery kraje: Argentynę, Brazylię, Urugwaj i Paragwaj (Tratado de Asunción 1991). Pierwsze rozszerzenie Mercosur nastąpiło 4 lipca 2006 r., kiedy to w struktury ugrupowania włączono Wenezuelę (Protocolo de adhesión 2006). Dziewięć lat później Mercosur powiększył się po raz kolejny - 17 lipca 2015 r. wszystkie strony podpisały protokół przystąpienia do ugrupowania Boliwii. Obecnie trwają prace ratyfikacyjne umożliwiające Boliwii stanie się pełnoprawnym członkiem Mercosur ${ }^{1}$ i jednocześnie zachowanie jej członkostwa w CAN (Protocolo de adhesión 2015).

\footnotetext{
* Kamil Majcher - magister, Wyższa Szkoła Bankowa we Wrocławiu, Wydział Finansów i Zarządzania,kamilma@onet.pl.

${ }^{1}$ Boliwia w przedmiotowym tekście jest członkiem stowarzyszonym z Mercosur. Podpisanie w 2015 r. protokołu przystąpienia (Protocolo de adhesión) zainicjowało długotrwałą procedurę akcesyjną, która trwa do dzisiaj.
} 
Status kraju stowarzyszonego z Mercosur uzyskały także Chile (ACE 1996) oraz Surinam i Gujana (AMA 2015).

Kwestią istotną dla gospodarek narodowych krajów CAN oraz Mercosur jest handel międzynarodowy, który znacząco wpływa na zagregowaną wielkość PKB. Od relacji między eksportem a importem zależy to, czy podzielony PKB jest równy PKB wytworzonemu, mniejszy od wytworzonego czy od niego większy. Wzrost handlu skutkuje także wzrostem produktu krajowego poprzez efektywność gospodarowania. Prowadzi bowiem do specjalizacji i zawężania podstawowych obszarów działalności (Jaszczyński 2016, s. 376). Obecnie wzrasta znaczenie handlu międzynarodowego, a nowe kierunki specjalizacji sprzyjają poprawie konkurencyjności. Szczególne korzyści czerpią z tego kraje prowadzące politykę wzrostu napędzanego eksportem (Zielińska-Głębocka 2012, s. 49). Jednym ze skutecznych narzędzi wykorzystywanych do badania konkurencyjności danej gospodarki narodowej - zarówno w handlu światowym, jak i w porównaniu z określoną grupą państw czy blokiem gospodarczym - jest wskaźnik ujawnionych przewag komparatywnych Balassy, RCA (revealed comparative advantage).

Celem artykułu jest określenie przewag komparatywnych w handlu towarowym czterech krajów ugrupowania CAN nad pięcioma krajami ugrupowania Mercosur w latach 2007-2017. W tym celu zastosowano wskaźnik ujawnionych przewag komparatywnych Balassy oraz klasyfikację towarów SITC (standard international trade classification). Badanie poprzedzono omówieniem międzynarodowych obrotów towarowych CAN z Mercosur.

Materiał statystyczny wykorzystany w artykule pobrano z bazy danych Komisji Gospodarczej Narodów Zjednoczonych ds. Ameryki Łacińskiej i Karaibów (CEPAL) oraz Światowej Organizacji Handlu (WTO).

\section{Intensywność i saldo obrotów towarowych CAN z Mercosur}

Warto zacząć od zobrazowania rozmiarów międzynarodowej wymiany towarowej - tj. eksportu, importu oraz salda obrotów towarowych - prowadzonej przez CAN z Mercosur jako partnerem handlowym w odniesieniu do poszczególnych gospodarek narodowych: Kolumbii, Peru, Ekwadoru i Boliwii. Na podstawie danych zamieszczonych w Tabeli 1 można stwierdzić, że w latach 2007-2017 intensywność międzynarodowej wymiany towarowej między CAN a Mercosur znacznie osłabła. 


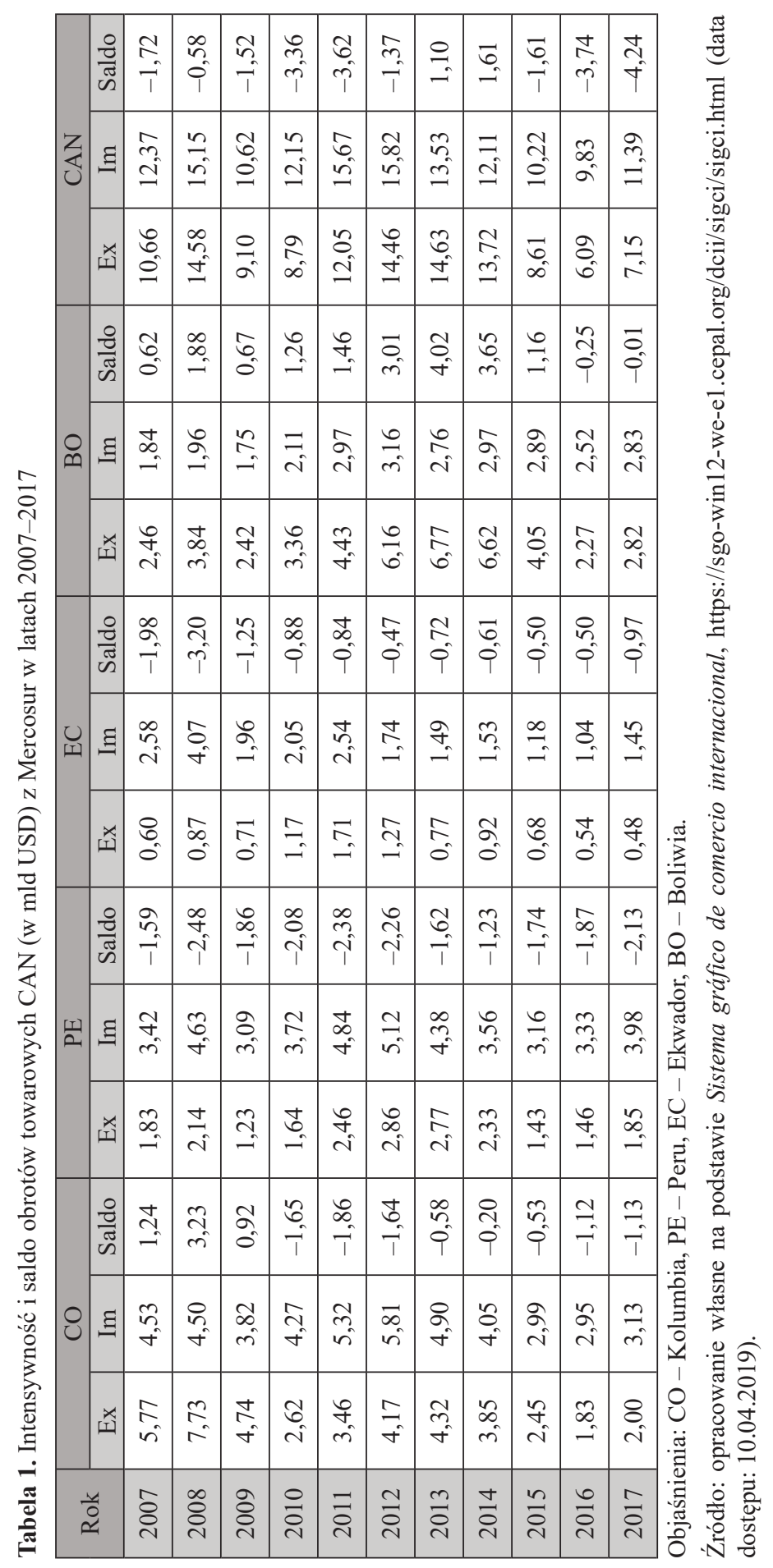


Wielkość eksportu CAN do omawianych krajów wynosiła w $2007 \mathrm{r}$. 10,66 mld USD, a w 2017 r. 7,15 mld USD, co oznacza, że zmniejszył się on o 3,51 mld USD (32,93\%). Zmniejszył się również import - o 0,98 mld USD, z 12,37 mld USD w 2007 r. do 11,39 mld USD w 2017 r. (spadek o 7,92\%). W związku z tym zwiększył się deficyt bilansu obrotów towarowych CAN w 2017 r., który oscylował wokół -4,24 mld USD, podczas gdy jego poziom w 2007 r. ustalono na $-1,72$ mld USD, wzrósł on zatem o $59,43 \%$. Warto podkreślić, że w badanym okresie, z wyjątkiem lat 2012 i 2013, saldo obrotów towarowych CAN wykazywało wartości ujemne.

Biorąc pod uwagę indywidualne gospodarki narodowe krajów CAN, w latach 2007-2017 można było zauważyć znaczny spadek wielkości eksportu Kolumbii - o 3,77 mld USD (65,34\%). Spadek sprzedaży kolumbijskich towarów na rynki krajów należące do Mercosur bezpośrednio wpłynął na ogólne wyniki CAN. W przypadku Ekwadoru także można było zauważyć, choć w mniejszym stopniu, spadek wielkości eksportu - o 0,12 mld USD (20\%). W przypadku Peru i Boliwii sprzedaż towarów na rynek Mercosur wzrosła odpowiednio o 0,02 mld USD (1,09\%) i 0,36 mld USD (14,63\%). Ponadto Boliwia jako jedyny kraj CAN w ciągu dziewięciu lat osiągała dodatnie saldo obrotów towarowych z Mercosur. Odwrotnie było w przypadku Peru i Ekwadoru.

\section{Struktura i dynamika obrotów towarowych CAN z Mercosur}

W badaniu struktury międzynarodowej wymiany towarowej między ugrupowaniami CAN i Mercosur posłużono się standardową klasyfikacją handlu międzynarodowego (SITC).

$\mathrm{Z}$ danych zaprezentowanych w Tabeli 2 wynika, że eksport CAN do Mercosur w latach 2007-2017 w dużej mierze opierał się na sprzedaży dóbr zaklasyfikowanych go segmentu trzeciego (paliwa mineralne, smary i podobne materiały). Najwyższą wartość, w liczbach bezwzględnych, osiągnął on w roku $2014 \mathrm{r}$. - 7,997 mld USD. W 2017 r. wielkość eksportu omawianego segmentu wzrosła w stosunku do 2007 r. o 1,362 mld USD, tj. o 54,09\%.

W 2007 r. istotną rolę w eksporcie CAN odgrywały segmenty szósty (artykuły przemysłowe) i ósmy (inne wyroby przemysłowe). W obu przypadkach w roku końcowym nastąpił istotny spadek eksportu - odpowiednio o 74,92\% i 89,47\%. Warto podkreślić, że jego przyczyną było w dużej mierze zmniejszenie eksportu na rynek wenezuelski odpowiednio o 94,22\% (segment szósty) i 98,31\% (segment ósmy). Eksport CAN w 2017 r. wzrósł - o 14,77\%, tj. 0,112 mld USD - w przypadku segmentu piątego (chemikalia i produkty podobne). 
Tabela 2. Eksport CAN (w mld USD) do Mercosur według klasyfikacji SITC oraz zmiany zachodzące w latach 2007-2017

\begin{tabular}{|c|c|c|c|c|c|c|c|}
\hline \multirow[b]{2}{*}{$\begin{array}{l}\text { Segment } \\
\text { SITC }\end{array}$} & \multirow{2}{*}{$\begin{array}{c}\text { Kraj } \\
\text { (z grupy } \\
\text { Merco- } \\
\text { sur) } \\
\end{array}$} & 2007 & 2010 & 2014 & 2017 & \multirow{2}{*}{$\begin{array}{c}\text { Zmiana } \\
\text { w } 2017 \text { r. } \\
\text { (w mld } \\
\text { USD) }\end{array}$} & \multirow{2}{*}{$\begin{array}{c}\text { Zmiana } \\
\text { w } 2017 \mathrm{r} . \\
(\mathrm{w} \%) \\
100=2007\end{array}$} \\
\hline & & \multicolumn{4}{|c|}{ mld USD } & & \\
\hline \multirow{6}{*}{0} & $\mathrm{VE}$ & 1,160 & 0,508 & 0,885 & 0,094 & $-1,066$ & 8,10 \\
\hline & AR & 0,090 & 0,134 & 0,248 & 0,321 & 0,231 & 356,67 \\
\hline & $\mathrm{BR}$ & 0,050 & 0,102 & 0,205 & 0,138 & 0,088 & 276,00 \\
\hline & UY & 0,006 & 0,010 & 0,024 & 0,031 & 0,025 & 516,67 \\
\hline & PY & 0,002 & 0,005 & 0,010 & 0,006 & 0,004 & 300,00 \\
\hline & $\sum$ & 1,308 & 0,759 & 1,372 & 0,590 & $-0,718$ & 45,11 \\
\hline \multirow{6}{*}{1} & $\mathrm{VE}$ & 0,012 & 0,004 & 0,002 & 0,002 & $-0,010$ & 16,67 \\
\hline & AR & 0,000 & 0,000 & 0,000 & 0,000 & 0,000 & - \\
\hline & $\mathrm{BR}$ & 0,004 & 0,000 & 0,002 & 0,001 & $-0,003$ & 25,00 \\
\hline & UY & 0,000 & 0,000 & 0,000 & 0,000 & 0,000 & - \\
\hline & PY & 0,000 & 0,000 & 0,000 & 0,000 & 0,000 & - \\
\hline & $\sum$ & 0,016 & 0,004 & 0,004 & 0,003 & $-0,013$ & 18,75 \\
\hline \multirow{6}{*}{2} & $\mathrm{VE}$ & 0,149 & 0,034 & 0,016 & 0,001 & $-0,148$ & 0,67 \\
\hline & $\mathrm{AR}$ & 0,074 & 0,058 & 0,042 & 0,029 & $-0,045$ & 39,19 \\
\hline & $\mathrm{BR}$ & 0,256 & 0,264 & 0,549 & 0,728 & 0,472 & 284,38 \\
\hline & UY & 0,005 & 0,013 & 0,019 & 0,017 & 0,012 & 340,00 \\
\hline & PY & 0,002 & 0,002 & 0,005 & 0,006 & 0,004 & 300,00 \\
\hline & $\sum$ & 0,486 & 0,371 & 0,631 & 0,781 & 0,295 & 160,70 \\
\hline \multirow{6}{*}{3} & $\mathrm{VE}$ & 0,138 & 0,354 & 0,407 & 0,011 & $-0,127$ & 7,97 \\
\hline & AR & 0,389 & 0,563 & 2,622 & 1,291 & 0,902 & 331,88 \\
\hline & $\mathrm{BR}$ & 1,970 & 2,774 & 4,926 & 2,523 & 0,553 & 128,07 \\
\hline & UY & 0,000 & 0,027 & 0,006 & 0,019 & 0,019 & - \\
\hline & $\mathrm{PY}$ & 0,021 & 0,004 & 0,036 & 0,036 & 0,015 & 171,43 \\
\hline & $\sum$ & 2,518 & 3,722 & 7,997 & 3,880 & 1,362 & 154,09 \\
\hline \multirow{6}{*}{4} & $\overline{\mathrm{VE}}$ & 0,130 & 0,181 & 0,129 & 0,028 & $-0,102$ & 21,54 \\
\hline & $\mathrm{AR}$ & 0,004 & 0,006 & 0,004 & 0,010 & 0,006 & 250,00 \\
\hline & $\mathrm{BR}$ & 0,022 & 0,005 & 0,030 & 0,061 & 0,039 & 277,27 \\
\hline & UY & 0,000 & 0,001 & 0,000 & 0,002 & 0,002 & - \\
\hline & PY & 0,000 & 0,000 & 0,001 & 0,000 & 0,000 & - \\
\hline & $\sum$ & 0,156 & 0,193 & 0,164 & 0,101 & $-0,055$ & 64,74 \\
\hline \multirow{6}{*}{5} & $\mathrm{VE}$ & 0,585 & 0,410 & 0,697 & 0,123 & $-0,462$ & 21,03 \\
\hline & $\mathrm{AR}$ & 0,050 & 0,079 & 0,095 & 0,140 & 0,090 & 280,00 \\
\hline & $\mathrm{BR}$ & 0,112 & 0,403 & 0,620 & 0,574 & 0,462 & 512,50 \\
\hline & UY & 0,007 & 0,012 & 0,012 & 0,021 & 0,014 & 300,00 \\
\hline & PY & 0,004 & 0,011 & 0,019 & 0,012 & 0,008 & 300,00 \\
\hline & $\sum$ & 0,758 & 0,915 & 1,443 & 0,870 & 0,112 & 114,78 \\
\hline
\end{tabular}


Tabela 2 (cd.)

\begin{tabular}{|c|c|c|c|c|c|c|c|}
\hline \multirow{2}{*}{$\begin{array}{l}\text { Segment } \\
\text { SITC }\end{array}$} & \multirow{2}{*}{$\begin{array}{c}\text { Kraj } \\
\text { (z grupy } \\
\text { Merco- } \\
\text { sur) }\end{array}$} & 2007 & 2010 & 2014 & 2017 & \multirow{2}{*}{$\begin{array}{c}\text { Zmiana } \\
\text { w } 2017 \text { r. } \\
\text { (w mld } \\
\text { USD) }\end{array}$} & \multirow{2}{*}{$\begin{array}{c}\text { Zmiana } \\
\text { w } 2017 \text { r. } \\
(w \%) \\
100=2007\end{array}$} \\
\hline & & \multicolumn{4}{|c|}{ mld USD } & & \\
\hline \multirow{6}{*}{6} & VE & 1,281 & 0,654 & 0,610 & 0,074 & $-1,207$ & 5,78 \\
\hline & AR & 0,050 & 0,056 & 0,054 & 0,054 & 0,004 & 108,00 \\
\hline & $\mathrm{BR}$ & 0,757 & 0,730 & 0,681 & 0,370 & $-0,387$ & 48,88 \\
\hline & UY & 0,003 & 0,004 & 0,008 & 0,010 & 0,007 & 333,33 \\
\hline & PY & 0,002 & 0,006 & 0,012 & 0,017 & 0,015 & 850,00 \\
\hline & $\sum$ & 2,093 & 1,450 & 1,365 & 0,525 & $-1,568$ & 25,08 \\
\hline \multirow{6}{*}{7} & $\overline{\mathrm{VE}}$ & 1,523 & 0,425 & 0,150 & 0,076 & $-1,447$ & 4,99 \\
\hline & $\mathrm{AR}$ & 0,006 & 0,034 & 0,038 & 0,066 & 0,060 & 1100,00 \\
\hline & $\mathrm{BR}$ & 0,014 & 0,102 & 0,043 & 0,055 & 0,041 & 392,86 \\
\hline & UY & 0,000 & 0,001 & 0,008 & 0,003 & 0,003 & - \\
\hline & PY & 0,001 & 0,003 & 0,011 & 0,012 & 0,011 & 1200,00 \\
\hline & $\sum$ & 1,544 & 0,565 & 0,250 & 0,212 & $-1,332$ & 13,73 \\
\hline \multirow{6}{*}{8} & $\mathrm{VE}$ & 1,718 & 0,683 & 0,289 & 0,029 & $-1,689$ & 1,69 \\
\hline & $\mathrm{AR}$ & 0,023 & 0,045 & 0,040 & 0,056 & 0,033 & 243,48 \\
\hline & $\mathrm{BR}$ & 0,021 & 0,074 & 0,145 & 0,085 & 0,064 & 404,76 \\
\hline & UY & 0,003 & 0,006 & 0,009 & 0,009 & 0,006 & 300,00 \\
\hline & PY & 0,002 & 0,005 & 0,009 & 0,007 & 0,005 & 350,00 \\
\hline & $\sum$ & 1,767 & 0,813 & 0,492 & 0,186 & $-1,581$ & 10,53 \\
\hline \multirow{6}{*}{9} & VE & 0,004 & 0,000 & 0,000 & 0,000 & $-0,004$ & 0,00 \\
\hline & AR & 0,001 & 0,000 & 0,001 & 0,001 & 0,000 & 100,00 \\
\hline & $\mathrm{BR}$ & 0,000 & 0,001 & 0,001 & 0,001 & 0,001 & - \\
\hline & UY & 0,000 & 0,000 & 0,000 & 0,000 & 0,000 & - \\
\hline & PY & 0,000 & 0,001 & 0,000 & 0,000 & 0,000 & - \\
\hline & $\sum$ & 0,005 & 0,002 & 0,002 & 0,002 & $-0,003$ & 40,00 \\
\hline
\end{tabular}

Objaśnienia: 0 - żywność i żywe zwierzęta, 1 - napoje i tytoń, 2 - surowce (z wyłączeniem paliw mineralnych), 3 - paliwa mineralne, smary i podobne materiały, 4 - oleje i thuszcze, 5 - chemikalia i produkty podobne, 6 - artykuły przemysłowe, 7 - maszyny i sprzęt transportowy, 8 - inne wyroby przemysłowe, 9 - pozostałe towary niesklasyfikowane.

VE - Wenezuela, AR - Argentyna, BR - Brazylia, UY - Urugwaj, PY - Paragwaj.

Źródło: opracowanie własne na podstawie Sistema gráfico de comercio internacional, https://sgo-win12-we-e1.cepal.org/dcii/sigci/sigci.html (data dostępu: 10.04.2019).

Zgodnie z danymi zawartymi w Tabeli 3 import CAN z Mercosur w latach 2007-2017 opierał się głównie na zakupie dóbr zaklasyfikowanych do segmentu siódmego (maszyny i sprzęt transportowy). W badanym okresie wartość importu segmentu siódmego wynosiła 3,000 mld USD. Należy jednak zaznaczyć, że odnotowano niewielki, o 1,27\%, spadek importu omawianych dóbr, który również był wynikiem zmniejszenia importu z Wenezueli - o 98,39\%, tj. o 0,306 mld USD - w 2017 r. Z kolei Brazylia będąca głównym dostawcą tych dóbr do CAN odnotowała wzrost sprzedaży o 7,2\% (0,163 mld USD). 
Tabela 3. Import CAN (w mld USD) z Mercosur według klasyfikacji SITC oraz zmiany zachodzące w latach 2007-2017

\begin{tabular}{|c|c|c|c|c|c|c|c|}
\hline \multirow{2}{*}{$\begin{array}{l}\text { Segment } \\
\text { SITC }\end{array}$} & \multirow{2}{*}{$\begin{array}{c}\text { Kraj } \\
\text { (z grupy } \\
\text { Merco- } \\
\text { sur) }\end{array}$} & 2007 & 2010 & 2014 & 2017 & \multirow{2}{*}{$\begin{array}{c}\text { Zmiana } \\
\text { w } 2017 \text { r. } \\
\text { (w mld } \\
\text { USD) }\end{array}$} & \multirow{2}{*}{$\begin{array}{c}\text { Zmiana } \\
\text { w } 2017 \text { r. } \\
(\mathbf{w} \%) \\
100=2007\end{array}$} \\
\hline & & & ml & SD & & & \\
\hline \multirow{6}{*}{0} & VE & 0,044 & 0,003 & 0,006 & 0,005 & $-0,039$ & 11,36 \\
\hline & $\mathrm{AR}$ & 1,030 & 1,780 & 1,216 & 0,940 & $-0,090$ & 91,26 \\
\hline & BR & 0,220 & 0,482 & 0,390 & 0,572 & 0,352 & 260,00 \\
\hline & UY & 0,047 & 0,093 & 0,184 & 0,183 & 0,136 & 389,36 \\
\hline & PY & 0,143 & 0,243 & 0,148 & 0,152 & 0,009 & 106,29 \\
\hline & $\sum$ & 1,484 & 2,601 & 1,944 & 1,852 & 0,368 & 124,80 \\
\hline \multirow{6}{*}{1} & VE & 0,001 & 0,001 & 0,000 & 0,000 & $-0,001$ & 0,00 \\
\hline & $\mathrm{AR}$ & 0,028 & 0,034 & 0,046 & 0,048 & 0,020 & 171,43 \\
\hline & $\mathrm{BR}$ & 0,015 & 0,012 & 0,022 & 0,024 & 0,009 & 160,00 \\
\hline & UY & 0,000 & 0,000 & 0,008 & 0,004 & 0,004 & - \\
\hline & PY & 0,001 & 0,001 & 0,013 & 0,007 & 0,006 & 700,00 \\
\hline & $\sum$ & 0,045 & 0,048 & 0,089 & 0,083 & 0,038 & 184,44 \\
\hline \multirow{6}{*}{2} & $\mathrm{VE}$ & 0,016 & 0,006 & 0,004 & 0,001 & $-0,015$ & 6,25 \\
\hline & $\mathrm{AR}$ & 0,033 & 0,099 & 0,137 & 0,059 & 0,026 & 178,79 \\
\hline & $\mathrm{BR}$ & 0,143 & 0,120 & 0,111 & 0,124 & $-0,019$ & 86,71 \\
\hline & UY & 0,002 & 0,002 & 0,003 & 0,014 & 0,012 & 700,00 \\
\hline & PY & 0,021 & 0,025 & 0,065 & 0,058 & 0,037 & 276,19 \\
\hline & $\sum$ & 0,215 & 0,252 & 0,320 & 0,256 & 0,041 & 119,07 \\
\hline \multirow{6}{*}{3} & VE & 1,182 & 0,823 & 0,092 & 0,021 & $-1,161$ & 1,78 \\
\hline & $\mathrm{AR}$ & 0,199 & 0,092 & 0,480 & 0,553 & 0,354 & 277,89 \\
\hline & $\mathrm{BR}$ & 0,425 & 0,309 & 0,215 & 0,259 & $-0,166$ & 60,94 \\
\hline & UY & 0,054 & 0,005 & 0,001 & 0,001 & $-0,053$ & 1,85 \\
\hline & PY & 0,000 & 0,002 & 0,038 & 0,001 & 0,001 & - \\
\hline & $\sum$ & 1,860 & 1,231 & 0,826 & 0,835 & $-1,025$ & 44,89 \\
\hline \multirow{6}{*}{4} & VE & 0,000 & 0,000 & 0,000 & 0,001 & 0,001 & - \\
\hline & $\mathrm{AR}$ & 0,386 & 0,434 & 0,300 & 0,407 & 0,021 & 105,44 \\
\hline & $\mathrm{BR}$ & 0,009 & 0,033 & 0,049 & 0,053 & 0,044 & 588,89 \\
\hline & UY & 0,000 & 0,000 & 0,000 & 0,000 & 0,000 & - \\
\hline & PY & 0,003 & 0,000 & 0,018 & 0,001 & $-0,002$ & 33,33 \\
\hline & $\sum$ & 0,398 & 0,467 & 0,367 & 0,462 & 0,064 & 116,08 \\
\hline
\end{tabular}


Tabela 3 (cd.)

\begin{tabular}{|c|c|c|c|c|c|c|c|}
\hline \multirow{2}{*}{$\begin{array}{c}\text { Segment } \\
\text { SITC }\end{array}$} & \multirow{2}{*}{$\begin{array}{c}\text { Kraj } \\
\text { (z grupy } \\
\text { Merco- } \\
\text { sur) } \\
\end{array}$} & 2007 & 2010 & 2014 & 2017 & \multirow{2}{*}{$\begin{array}{c}\text { Zmiana } \\
\text { w } 2017 \text { r. } \\
\text { (w mld } \\
\text { USD) }\end{array}$} & \multirow{2}{*}{$\begin{array}{c}\text { Zmiana } \\
\text { w } 2017 \text { r. } \\
(w \%) \\
100=2007\end{array}$} \\
\hline & & \multicolumn{4}{|c|}{ mld USD } & & \\
\hline \multirow{6}{*}{5} & VE & 0,459 & 0,197 & 0,314 & 0,145 & $-0,314$ & 31,59 \\
\hline & $\mathrm{AR}$ & 0,339 & 0,468 & 0,738 & 0,502 & 0,163 & 148,08 \\
\hline & BR & 0,705 & 1,128 & 1,393 & 1,282 & 0,577 & 181,84 \\
\hline & UY & 0,057 & 0,095 & 0,118 & 0,130 & 0,073 & 228,07 \\
\hline & PY & 0,027 & 0,029 & 0,059 & 0,050 & 0,023 & 185,19 \\
\hline & $\sum$ & 1,587 & 1,917 & 2,622 & 2,109 & 0,522 & 132,89 \\
\hline \multirow{6}{*}{6} & $\mathrm{VE}$ & 0,922 & 0,212 & 0,068 & 0,074 & $-0,848$ & 8,03 \\
\hline & $\mathrm{AR}$ & 0,276 & 0,348 & 0,275 & 0,134 & $-0,142$ & 48,55 \\
\hline & BR & 1,664 & 1,672 & 1,779 & 1,901 & 0,237 & 114,24 \\
\hline & UY & 0,014 & 0,016 & 0,012 & 0,013 & $-0,001$ & 92,86 \\
\hline & PY & 0,003 & 0,003 & 0,003 & 0,007 & 0,004 & 233,33 \\
\hline & $\sum$ & 2,879 & 2,251 & 2,137 & 2,129 & $-0,750$ & 73,95 \\
\hline \multirow{6}{*}{7} & $\mathrm{VE}$ & 0,311 & 0,024 & 0,015 & 0,005 & $-0,306$ & 1,61 \\
\hline & $\mathrm{AR}$ & 0,477 & 0,549 & 0,644 & 0,584 & 0,107 & 122,43 \\
\hline & $\mathrm{BR}$ & 2,263 & 2,323 & 2,476 & 2,426 & 0,163 & 107,20 \\
\hline & UY & 0,009 & 0,010 & 0,006 & 0,006 & $-0,003$ & 66,67 \\
\hline & PY & 0,002 & 0,001 & 0,002 & 0,002 & 0,000 & 100,00 \\
\hline & $\sum$ & 3,062 & 2,907 & 3,143 & 3,023 & $-0,039$ & 98,73 \\
\hline \multirow{6}{*}{8} & $\mathrm{VE}$ & 0,022 & 0,007 & 0,008 & 0,014 & $-0,008$ & 63,64 \\
\hline & AR & 0,099 & 0,110 & 0,090 & 0,075 & $-0,024$ & 75,76 \\
\hline & $\mathrm{BR}$ & 0,235 & 0,322 & 0,527 & 0,519 & 0,284 & 220,85 \\
\hline & UY & 0,006 & 0,008 & 0,007 & 0,005 & $-0,001$ & 83,33 \\
\hline & PY & 0,004 & 0,004 & 0,009 & 0,007 & 0,003 & 175,00 \\
\hline & $\sum$ & 0,366 & 0,451 & 0,641 & 0,620 & 0,254 & 169,40 \\
\hline \multirow{6}{*}{9} & $\mathrm{VE}$ & 0,001 & 0,001 & 0,000 & 0,001 & 0,000 & 100,00 \\
\hline & $\mathrm{AR}$ & 0,005 & 0,002 & 0,001 & 0,002 & $-0,003$ & 40,00 \\
\hline & $\mathrm{BR}$ & 0,037 & 0,012 & 0,022 & 0,016 & $-0,021$ & 43,24 \\
\hline & UY & 0,000 & 0,000 & 0,000 & 0,000 & 0,000 & - \\
\hline & PY & 0,000 & 0,000 & 0,000 & 0,000 & 0,000 & - \\
\hline & $\sum$ & 0,043 & 0,015 & 0,023 & 0,019 & $-0,024$ & 44,19 \\
\hline
\end{tabular}

Źródło: opracowanie własne na podstawie Sistema gráfico de comercio internacional, https://sgo-win12-we-e1.cepal.org/dcii/sigci/sigci.html (data dostępu: 10.04.2019). 
Mimo że istotnym elementem importu CAN w analizowanym okresie były również dobra należące do segmentu szóstego (artykuły przemysłowe), to w 2017 r. import dóbr z tego segmentu znacznie się zmniejszył - o 26,05\%. Największy spadek (o 91,97\%) odnotowano w przypadku importu z Wenezueli, która wraz z Brazylią jest głównym dostawcą dóbr tego segmentu. W liczbach bezwzględnych najwyższy wzrost zakupu towarów odnotowano w przypadku segmentu piątego (chemikalia i podobne produkty): o 0,522 mld USD, tj. o 32,89\%, głównie za sprawą importu z Brazylii (wzrost o 0,577 mld USD) oraz segmentu zerowego (żywność i żywe zwierzęta): o 0,368 mld USD, czyli o 24,80\%.

Wykres 1 przedstawia saldo obrotów towarowych CAN z Mercosur w latach 2007-2017. W 2007 r. dodatni bilans wymiany towarowej odnotowano w przypadku dóbr zaklasyfikowanych do segmentów: ósmego (inne wyroby przemysłowe), na poziomie 1,401 mld USD, trzeciego (paliwa mineralne, smary, podobne materiały) oraz drugiego (surowce $\mathrm{z}$ wyłączeniem paliw mineralnych). $\mathrm{W}$ pozostałych przypadkach CAN miał ujemny bilans obrotów towarowych.

Wykres 1. Saldo obrotów towarowych CAN (w mld USD) według segmentów klasyfikacji SITC (0-9) w latach: 2007, 2010, 2014, 2017

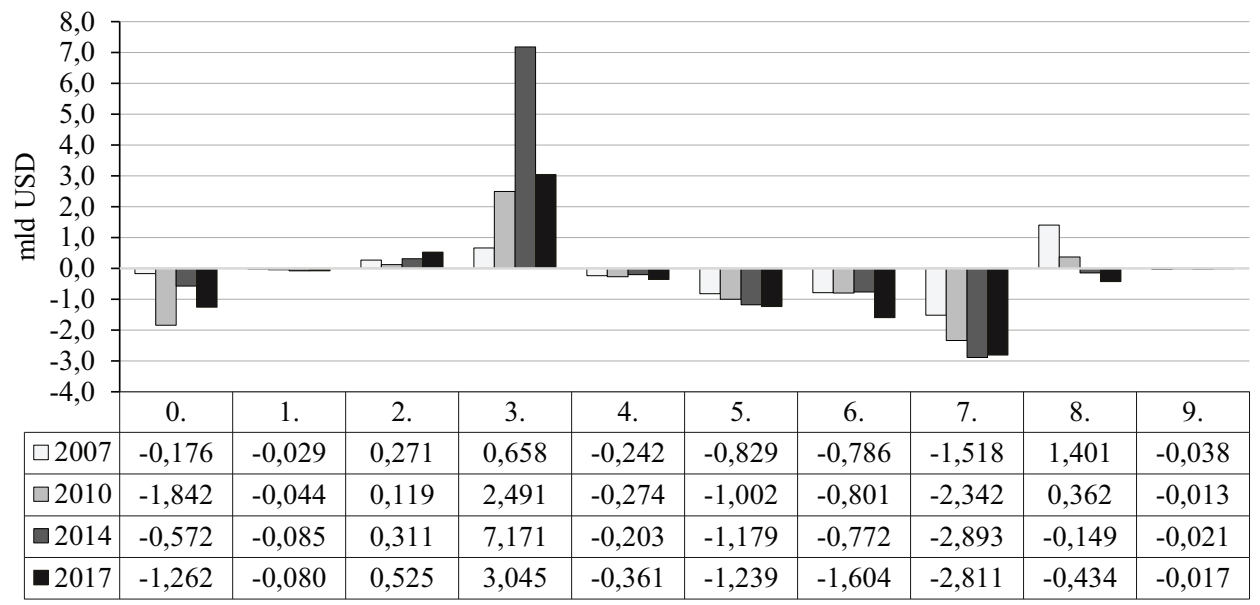

Źródło: opracowanie własne na podstawie Tabel 2-3.

W badanym okresie zwiększyło się ujemne saldo segmentów szóstego (artykuły przemysłowe) i siódmego (maszyny i sprzęt transportowy). Jednak w przypadku produktów przemysłu wydobywczego (segmenty drugi i trzeci) zauważa się coroczną nadwyżkę, która w 2014 r. wynosiła odpowiednio 0,311 mld USD i 7,171 mld USD. Z pewnością nadwyżka w handlu produktami przemysłu wydobywczego miała wpływ na ogólne saldo obrotów towarowych CAN w 2014 r., które wyniosło 1,61 mld USD (por. Tabela 1). Co ciekawe tempo wzrostu nadwyżki w przypadku segmentu trzeciego w 2014 r. w porównaniu z rokiem 2007 wyniosło $989,82 \%$. 


\section{Przewaga komparatywna CAN nad Mercosur w handlu towarami}

Na potrzeby badania wykorzystano wskaźnik ujawnionych korzyści komparatywnych (RCA), który wyraża łącznie korzyść konkurencyjną i komparatywną kraju. Wskaźnik ten jest mierzony jako relacja między udziałem eksportu dobra $n$ $\mathrm{z}$ kraju $i$ w całkowitym światowym eksporcie $w$ tego dobra a udziałem całkowitego eksportu kraju $i$ w całkowitym eksporcie światowym $w$ (Zielińska-Głębocka 2012, s. 75). Wartość wskaźnika RCA większa od 1 świadczy o przewadze komparatywnej. Wskaźnik można przedstawić następująco:

$$
R C A=\frac{\left(E x_{n}\right)_{i}}{\left(E x_{n}\right)_{w}} \div \frac{(E x)_{i}}{(E x)_{w}}
$$

Z danych przedstawionych w Tabeli 4 wynika, że w latach 2007-2017 ujawniono przewagę komparatywną CAN nad Mercosur w segmentach:

- trzecim: paliwa mineralne, smary i podobne materiały;

- ósmym: inne wyroby przemysłowe;

- dziewiątym: pozostałe towary niesklasyfikowane.

Tabela 4. Wskaźnik RCA dla ugrupowania CAN w latach 2007-2017

\begin{tabular}{|c|l|l|l|l|l|l|l|l|l|l|l|}
\hline $\begin{array}{c}\text { Segment } \\
\text { SITC }\end{array}$ & $\mathbf{2 0 0 7}$ & $\mathbf{2 0 0 8}$ & $\mathbf{2 0 0 9}$ & $\mathbf{2 0 1 0}$ & $\mathbf{2 0 1 1}$ & $\mathbf{2 0 1 2}$ & $\mathbf{2 0 1 3}$ & $\mathbf{2 0 1 4}$ & $\mathbf{2 0 1 5}$ & $\mathbf{2 0 1 6}$ & $\mathbf{2 0 1 7}$ \\
\hline 0 & 0,66 & 0,65 & 0,66 & 0,59 & 0,57 & 0,49 & 0,52 & 0,61 & 0,75 & 0,77 & 0,78 \\
\hline 1 & 0,13 & 0,1 & 0,11 & 0,13 & 0,11 & 0,11 & 0,14 & 0,16 & 0,19 & 0,18 & 0,17 \\
\hline 2 & $\mathbf{1 , 1}$ & 0,81 & 0,77 & 0,68 & 0,59 & 0,63 & 0,54 & 0,53 & 0,71 & 0,89 & 0,86 \\
\hline 3 & $\mathbf{3 , 2 2}$ & $\mathbf{3 , 8 2}$ & $\mathbf{3 , 4 8}$ & $\mathbf{4 , 0 1}$ & $\mathbf{4 , 5 6}$ & $\mathbf{4 , 5 2}$ & $\mathbf{6 , 7 0}$ & $\mathbf{5 , 4 8}$ & $\mathbf{5 , 0 3}$ & $\mathbf{4 , 5 5}$ & $\mathbf{3 , 9 4}$ \\
\hline 4 & 0,33 & 0,38 & 0,41 & 0,37 & 0,37 & 0,44 & 0,43 & 0,54 & 0,53 & 0,54 & 0,56 \\
\hline 5 & 0,58 & 0,63 & 0,62 & 0,64 & 0,56 & 0,51 & 0,57 & 0,57 & 0,74 & 0,71 & 0,65 \\
\hline 6 & 0,99 & 0,86 & 0,86 & 0,90 & 0,80 & 0,75 & 0,82 & 0,72 & 0,73 & 0,75 & 0,70 \\
\hline 7 & 0,18 & 0,15 & 0,17 & 0,13 & 0,14 & 0,14 & 0,11 & 0,13 & 0,15 & 0,15 & 0,13 \\
\hline 8 & $\mathbf{2 , 1 0}$ & $\mathbf{2 , 0 3}$ & $\mathbf{1 , 6 2}$ & $\mathbf{1 , 5 7}$ & $\mathbf{1 , 6 0}$ & $\mathbf{1 , 6 1}$ & $\mathbf{1 , 5 5}$ & $\mathbf{1 , 4 3}$ & $\mathbf{1 , 5 6}$ & $\mathbf{1 , 5 5}$ & $\mathbf{1 , 3 9}$ \\
\hline 9 & $\mathbf{2 , 3 0}$ & $\mathbf{2 , 5 0}$ & $\mathbf{3 , 8 1}$ & $\mathbf{3 , 1 9}$ & 0,91 & $\mathbf{2 , 7 1}$ & $\mathbf{2 , 4 2}$ & $\mathbf{2 , 1 0}$ & $\mathbf{2 , 6 4}$ & $\mathbf{3 , 2 2}$ & $\mathbf{3 , 1 0}$ \\
\hline
\end{tabular}

Objaśnienia:

0 - żywność i żywe zwierzęta, 1 - napoje i tytoń, 2 - surowce (z wyłączeniem paliw mineralnych), 3 - paliwa mineralne, smary i podobne materiały, 4 - oleje i tłuszcze, 5 - chemikalia i produkty podobne, 6 - artykuły przemysłowe, 7 - maszyny i sprzęt transportowy, 8 - inne wyroby przemysłowe, 9 - pozostałe towary niesklasyfikowane.

Źródło: opracowanie własne na podstawie Sistema gráfico de comercio internacional, https://sgo-win12-we-e1.cepal.org/dcii/sigci/sigci.html; International Trade and Market Access Data: www. wto.org/english/res_e/statis_e/statis_bis_e.htm?solution=WTO\&path=/Dashboards/MAPS\&file=Map.wcdf\&bookmarkState $=\{\% 22 \mathrm{impl} \% 22: \% 22$ client $\% 22, \% 22$ params $\% 22:\{\% 22$ langParam\%22:\%22en\%22\}\} (data dostępu: 10.04.2019). 
Bezsprzecznie największą przewagę odnotowano w przypadku dóbr zaklasyfikowanych do segmentu trzeciego. W ciągu dekady RCA dla tej grupy towarów nie spadło poniżej 3,22, a najwyższą wartość, na poziomie 6,70 , osiągnął on w 2013 r. W badanym okresie (z wyjątkiem 2011 r.) CAN miał przewagę nad Mercosur w segmencie dziewiątym, a najwyższa wartość RCA przypadła na 2009 r. - 3,81. W przypadku segmentu ósmego RCA wynosiło początkowo 2,30, ale ostatecznie spadło do 1,39. W 2007 r. CAN osiągnęło przewagę komparatywną również w segmencie drugim (surowce z wył. paliw mineralnych), jednak w kolejnych latach RCA przyjmował wartości poniżej 1.

W badanym okresie RCA Kolumbii był istotnie zbliżony do wartości osiągniętych przez CAN. Ujawniona przewaga komparatywna w segmencie trzecim była dość znacząca, a najwyższa wartość RCA przypadła na 2013 r. $(9,47)$.

Tabela 5. Wskaźnik RCA dla Kolumbii w latach 2007-2017

\begin{tabular}{|c|c|c|c|c|c|c|c|c|c|c|c|}
\hline $\begin{array}{c}\text { Segment } \\
\text { SITC }\end{array}$ & $\mathbf{2 0 0 7}$ & $\mathbf{2 0 0 8}$ & $\mathbf{2 0 0 9}$ & $\mathbf{2 0 1 0}$ & $\mathbf{2 0 1 1}$ & $\mathbf{2 0 1 2}$ & $\mathbf{2 0 1 3}$ & $\mathbf{2 0 1 4}$ & $\mathbf{2 0 1 5}$ & $\mathbf{2 0 1 6}$ & $\mathbf{2 0 1 7}$ \\
\hline 0 & 0,60 & 0,55 & 0,51 & 0,42 & 0,37 & 0,30 & 0,30 & 0,36 & 0,49 & 0,53 & 0,51 \\
\hline 1 & 0,17 & 0,11 & 0,08 & 0,07 & 0,07 & 0,06 & 0,08 & 0,10 & 0,12 & 0,10 & 0,12 \\
\hline 2 & 0,39 & 0,28 & 0,26 & 0,20 & 0,13 & 0,14 & 0,14 & 0,14 & 0,22 & 0,25 & 0,20 \\
\hline 3 & $\mathbf{3 , 9 1}$ & $\mathbf{4 , 7 1}$ & $\mathbf{4 , 9 4}$ & $\mathbf{5 , 8 7}$ & $\mathbf{6 , 6 9}$ & $\mathbf{6 , 6 1}$ & $\mathbf{9 , 4 7}$ & $\mathbf{7 , 8 3}$ & $\mathbf{8 , 0 7}$ & $\mathbf{7 , 8 9}$ & $\mathbf{6 , 9 4}$ \\
\hline 4 & 0,26 & 0,28 & 0,20 & 0,15 & 0,20 & 0,19 & 0,20 & 0,30 & 0,40 & 0,38 & 0,60 \\
\hline 5 & $\mathbf{1 , 2 0}$ & $\mathbf{1 , 1 6}$ & $\mathbf{1 , 1 3}$ & $\mathbf{1 , 0 9}$ & 0,89 & 0,84 & $\mathbf{1 , 0 0}$ & $\mathbf{1 , 0 3}$ & $\mathbf{1 , 4 6}$ & $\mathbf{1 , 4 7}$ & $\mathbf{1 , 3 1}$ \\
\hline 6 & $\mathbf{1 , 0 9}$ & 0,90 & 0,91 & 0,76 & 0,59 & 0,60 & 0,57 & 0,53 & 0,60 & 0,62 & 0,52 \\
\hline 7 & 0,38 & 0,27 & 0,28 & 0,20 & 0,20 & 0,16 & 0,18 & 0,20 & 0,27 & 0,29 & 0,26 \\
\hline 8 & $\mathbf{2 , 3 7}$ & $\mathbf{2 , 5 7}$ & $\mathbf{1 , 7 7}$ & $\mathbf{1 , 6 6}$ & $\mathbf{1 , 5 5}$ & $\mathbf{1 , 5 4}$ & $\mathbf{1 , 4 7}$ & $\mathbf{1 , 3 9}$ & $\mathbf{1 , 8 2}$ & $\mathbf{1 , 8 3}$ & $\mathbf{1 , 6 4}$ \\
\hline 9 & 0,72 & 0,95 & $\mathbf{1 , 6 8}$ & $\mathbf{1 , 7 0}$ & 0,45 & $\mathbf{1 , 5 0}$ & $\mathbf{1 , 1 2}$ & 0,83 & 0,94 & $\mathbf{1 , 5 8}$ & $\mathbf{1 , 5 8}$ \\
\hline
\end{tabular}

Źródło: opracowanie własne na podstawie Sistema gráfico de comercio internacional, https:// sgo-win12-we-e1.cepal.org/dcii/sigci/sigci.html; International Trade and Market Access Data, www.wto.org/english/res_e/statis_e/statis_bis_e.htm?solution=WTO\&path=/Dashboards/MAPS\&file=Map.wcdf\&bookmarkState $=\{\% 22 \overline{\mathrm{impl}} \% 22: \% 22 \mathrm{client} \% 22, \% 22$ params $\% 22:\{\% 22 \mathrm{langPa}-$ ram\%22:\%22en\%22\}\} (data dostępu: 10.04.2019).

W przypadku segmentu ósmego (inne wyroby przemysłowe) RCA osiągnęło najwyższą wartość - na poziomie 2,57 - w 2008 r. Odnotowano też przewagę w segmencie piątym (chemikalia i produkty podobne) w kolejnych dziesięciu latach z najwyższą wartością RCA w 2016 r. $(1,47)$.

Kolumbia w badanym okresie miała przewagę komparatywną nad Mercosur w segmencie dziewiątym (pozostałe towary niesklasyfikowane), a najwyższa wartość wskaźnika przypadła na 2010 r. $(1,70)$. Warto zaznaczyć, że w 2008 r. odnotowano przewagę komparatywną także w przypadku segmentu szóstego (artykuły przemysłowe), na poziomie 1,09, jednak Kolumbii nie udało się jej utrzymać w kolejnych latach. 
Zgodnie z Tabelą 6 Peru osiągnęło wartości RCA powyżej jedności w pięciu segmentach towarowych SITC. Kraj ten jako jedyny członek CAN w badanym okresie miał przewagę komparatywną nad Mercosur w segmentach drugim (surowce z wył. paliw mineralnych) i szóstym (artykuły przemysłowe). Najwyższą przewagę w przypadku pierwszego z nich odnotowano w 2007 r. $(2,18)$. Uwarunkowania geologiczne Peru i obfite zasoby naturalnych surowców mineralnych, m.in. złota, cynku, miedzi, molibdenu i wolframu, wpłynęły na zawężanie specjalizacji w międzynarodowym handlu towarami tego kraju (INGEMMET 2018). Jeśli chodzi o segment szósty, to w 2017 r. wartość wskaźnika wyraźnie się zmniejszyła - do 1,02 .

Tabela 6. Wskaźnik RCA dla Peru w latach 2007-2017

\begin{tabular}{|c|c|c|c|c|c|c|c|c|c|c|c|}
\hline $\begin{array}{c}\text { Segment } \\
\text { SITC }\end{array}$ & $\mathbf{2 0 0 7}$ & $\mathbf{2 0 0 8}$ & $\mathbf{2 0 0 9}$ & $\mathbf{2 0 1 0}$ & $\mathbf{2 0 1 1}$ & $\mathbf{2 0 1 2}$ & $\mathbf{2 0 1 3}$ & $\mathbf{2 0 1 4}$ & $\mathbf{2 0 1 5}$ & $\mathbf{2 0 1 6}$ & $\mathbf{2 0 1 7}$ \\
\hline 0 & 0,55 & 0,61 & 0,58 & 0,57 & 0,60 & 0,52 & 0,54 & 0,66 & 0,70 & 0,64 & 0,66 \\
\hline 1 & 0,04 & 0,04 & 0,06 & 0,10 & 0,09 & 0,13 & 0,16 & 0,16 & 0,16 & 0,18 & 0,15 \\
\hline 2 & $\mathbf{2 , 1 8}$ & $\mathbf{1 , 6 5}$ & $\mathbf{1 , 4 5}$ & $\mathbf{1 , 3 2}$ & $\mathbf{1 , 2 4}$ & $\mathbf{1 , 3 9}$ & $\mathbf{1 , 2 0}$ & $\mathbf{1 , 2 1}$ & $\mathbf{1 , 3 8}$ & $\mathbf{1 , 6 1}$ & $\mathbf{1 , 6 0}$ \\
\hline 3 & 0,90 & 0,94 & 0,79 & 0,97 & $\mathbf{1 , 0 1}$ & $\mathbf{1 , 1 3}$ & $\mathbf{1 , 8 3}$ & $\mathbf{1 , 4 4}$ & $\mathbf{1 , 0 7}$ & $\mathbf{1 , 0 7}$ & $\mathbf{1 , 0 1}$ \\
\hline 4 & 0,26 & 0,33 & 0,34 & 0,31 & 0,27 & 0,46 & 0,41 & 0,59 & 0,38 & 0,33 & 0,37 \\
\hline 5 & 0,34 & 0,41 & 0,34 & 0,43 & 0,46 & 0,42 & 0,44 & 0,47 & 0,51 & 0,45 & 0,41 \\
\hline 6 & $\mathbf{1 , 3 7}$ & $\mathbf{1 , 3 1}$ & $\mathbf{1 , 1 7}$ & $\mathbf{1 , 3 7}$ & $\mathbf{1 , 2 8}$ & $\mathbf{1 , 2 1}$ & $\mathbf{1 , 5 4}$ & $\mathbf{1 , 3 6}$ & $\mathbf{1 . 1 3}$ & $\mathbf{1 , 0 6}$ & $\mathbf{1 , 0 2}$ \\
\hline 7 & 0,03 & 0,04 & 0,07 & 0,06 & 0,06 & 0,06 & 0,06 & 0,09 & 0,09 & 0,06 & 0,06 \\
\hline 8 & $\mathbf{2 , 2 2}$ & $\mathbf{2 , 6 4}$ & $\mathbf{2 , 1 6}$ & $\mathbf{1 , 9 7}$ & $\mathbf{2 , 3 4}$ & $\mathbf{2 , 5 3}$ & $\mathbf{2 , 5 0}$ & $\mathbf{2 , 3 6}$ & $\mathbf{1 , 9 9}$ & $\mathbf{1 , 8 4}$ & $\mathbf{1 , 6 6}$ \\
\hline 9 & $\mathbf{5 , 0 7}$ & $\mathbf{6 , 1 7}$ & $\mathbf{8 , 8 2}$ & $\mathbf{6 , 8 2}$ & $\mathbf{2 , 0 0}$ & $\mathbf{5 , 4 3}$ & $\mathbf{5 , 5 4}$ & $\mathbf{4 , 1 5}$ & $\mathbf{5 , 2 2}$ & $\mathbf{5 , 8 1}$ & $\mathbf{5 , 3 2}$ \\
\hline
\end{tabular}

Źródło: opracowanie własne na podstawie Sistema gráfico de comercio internacional, https://sgo-win12-we-e1.cepal.org/dcii/sigci/sigci.html; International Trade and Market Access Data, www. wto.org/english/res_e/statis_e/statis_bis_e.htm?solution=WTO\&path=/Dashboards/MAPS\&file $=$ Map.wcdf\&bookmarkState $=\{\% \overline{2} 2 \mathrm{impl} \% 22: \% 22$ client $\% 22, \% 22$ params $\% 22:\{\% 22$ langParam\%22:\%22en\%22\}\} (data dostępu: 10.04.2019).

Peru wyróżnia się także ujawnioną przewagą komparatywną w segmentach ósmym (inne wyroby przemysłowe) oraz dziewiątym (pozostałe towary niesklasyfikowane). W przypadku pierwszego z nich najwyższy poziom RCA $(2,64)$ przypada na 2008 r. Warto zwrócić uwagę na wysoką przewagę Peru w segmencie dziewiątym - wartość RCA nie spadała poniżej 5,0 (z wyjątkiem 2011 i 2014 r.), a najwyższy poziom wskaźnika $(8,82)$ odnotowano w 2009 r. Począwszy od 2011 r., Peru ma przewagę komparatywną nad Mercosur także w segmencie trzecim (paliwa mineralne, smary i podobne materiały). Najwyższa wartość RCA przypadła na 2013 r. $(1,83)$, a stosunkowo niższa - na lata 2011 i $2017(1,01)$. 
Z Tabeli 7 wynika, że Ekwador jako jedyny kraj CAN ma przewagę komparatywną nad Mercosur w segmencie zerowym (żywność i żywe zwierzęta). W badanym okresie, z wyjątkiem 2012 r., wartość RCA oscylowała powyżej jedności, osiągając najwyższy poziom $(1,75) \mathrm{w} 2017 \mathrm{r}$.

Tabela 7. Wskaźnik RCA dla Ekwadoru w latach 2007-2017

\begin{tabular}{|c|c|c|c|c|c|c|c|c|c|c|c|}
\hline $\begin{array}{c}\text { Segment } \\
\text { SITC }\end{array}$ & $\mathbf{2 0 0 7}$ & $\mathbf{2 0 0 8}$ & $\mathbf{2 0 0 9}$ & $\mathbf{2 0 1 0}$ & $\mathbf{2 0 1 1}$ & $\mathbf{2 0 1 2}$ & $\mathbf{2 0 1 3}$ & $\mathbf{2 0 1 4}$ & $\mathbf{2 0 1 5}$ & $\mathbf{2 0 1 6}$ & $\mathbf{2 0 1 7}$ \\
\hline 0 & $\mathbf{1 , 0 7}$ & $\mathbf{1 , 0 0}$ & $\mathbf{1 , 2 2}$ & $\mathbf{1 , 1 1}$ & $\mathbf{1 , 0 9}$ & 0,82 & $\mathbf{1 , 0 8}$ & $\mathbf{1 , 1 7}$ & $\mathbf{1 , 5 3}$ & $\mathbf{1 , 6 4}$ & $\mathbf{1 , 7 5}$ \\
\hline 1 & 0,19 & 0,12 & 0,17 & 0,21 & 0,19 & 0,17 & 0,15 & 0,22 & 0,26 & 0,25 & 0,29 \\
\hline 2 & 0,27 & 0,23 & 0,27 & 0,21 & 0,17 & 0,20 & 0,19 & 0,20 & 0,28 & 0,31 & 0,27 \\
\hline 3 & $\mathbf{6 , 0 8}$ & $\mathbf{6 , 3 9}$ & $\mathbf{5 , 1 6}$ & $\mathbf{5 , 7 1}$ & $\mathbf{6 , 0 4}$ & $\mathbf{5 , 8 1}$ & $\mathbf{8 , 0 4}$ & $\mathbf{6 , 1 7}$ & $\mathbf{5 , 5 4}$ & $\mathbf{5 , 5 3}$ & $\mathbf{4 , 6 7}$ \\
\hline 4 & 0,31 & 0,37 & 0,55 & 0,46 & 0,63 & 0,63 & 0,54 & 0,55 & 0,65 & 0,71 & 0,65 \\
\hline 5 & 0,17 & 0,15 & 0,18 & 0,24 & 0,21 & 0,23 & 0,20 & 0,17 & 0,22 & 0,19 & 0,17 \\
\hline 6 & 0,18 & 0,19 & 0,29 & 0,30 & 0,29 & 0,28 & 0,30 & 0,26 & 0,31 & 0,35 & 0,32 \\
\hline 7 & 0,14 & 0,18 & 0,18 & 0,21 & 0,17 & 0,20 & 0,09 & 0,09 & 0,12 & 0,11 & 0,09 \\
\hline 8 & 0,38 & 0,37 & 0,43 & 0,70 & 0,49 & 0,44 & 0,41 & 0,45 & 0,49 & 0,49 & 0,40 \\
\hline 9 & 0,19 & 0,17 & 0,14 & 0,13 & 0,06 & 0,44 & 0,62 & $\mathbf{1 , 1 2}$ & $\mathbf{1 , 1 4}$ & 0,51 & 0,31 \\
\hline
\end{tabular}

Źródło: opracowanie własne na podstawie Sistema gráfico de comercio internacional, https:// sgo-win12-we-e1.cepal.org/dcii/sigci/sigci.html; International Trade and Market Access Data, www.wto.org/english/res_e/statis_e/statis_bis_e.htm?solution=WTO\&path=/Dashboards/MAPS\&file=Map.wcdf\&bookmarkState $=\{\% 22 \mathrm{impl} \% 22: \% 22$ client $\% 22, \% 22$ params $\% 22:\{\% 22$ langParam\%22:\%22en\%22\}\} (data dostępu: 10.04.2019).

Wysoki poziom RCA Ekwadoru odnotowano w segmencie trzecim (paliwa mineralne, smary i podobne materiały). Kraj ten miał znaczną przewagę nad Mercosur w 2013 r. $(8,04)$, ale nieco niższą w roku końcowym $(4,67)$. Również w przypadku segmentu dziewiątego (pozostałe towary niesklasyfikowane) Ekwador uzyskał przewagę komparatywną, jednak tylko w latach $2014(1,12)$ i 2015 $(1,14)$. Jeśli chodzi o pozostałe segmenty, to ich wyniki były mniejsze od jedności. Świadczy to o stosunkowo wąskiej specjalizacji Ekwadoru opierającej się głównie na dostępnych surowcach naturalnych.

Tabela 8 prezentuje wartości RCA dla Boliwii, która - podobnie jak pozostałe państwa należące do CAN - uzyskała wysoką przewagę komparatywną nad Mercosur, jeśli chodzi o dobra zaklasyfikowane do segmentu trzeciego (paliwa mineralne, smary i podobne materiały). Najwyższą wartość RCA tego segmentu odnotowano w 2013 r. - podobnie jak w przypadku Ekwadoru, wyniosła ona wtedy 7,71 .

Boliwia jako jedyny członek CAN uzyskała przewagę komparatywną w segmencie czwartym (oleje i thuszcze), osiągając najwyższy wynik w 2010 r. $(1,82)$ i nieco niższy w 2008 r. $(1,20)$. 
Tabela 8. Wskaźnik RCA Boliwii w latach 2007-2017

\begin{tabular}{|c|c|c|c|c|c|c|c|c|c|c|c|}
\hline $\begin{array}{c}\text { Segment } \\
\text { SITC }\end{array}$ & $\mathbf{2 0 0 7}$ & $\mathbf{2 0 0 8}$ & $\mathbf{2 0 0 9}$ & $\mathbf{2 0 1 0}$ & $\mathbf{2 0 1 1}$ & $\mathbf{2 0 1 2}$ & $\mathbf{2 0 1 3}$ & $\mathbf{2 0 1 4}$ & $\mathbf{2 0 1 5}$ & $\mathbf{2 0 1 6}$ & $\mathbf{2 0 1 7}$ \\
\hline 0 & 0,44 & 0,37 & 0,48 & 0,41 & 0,35 & 0,32 & 0,38 & 0,38 & 0,43 & 0,49 & 0,36 \\
\hline 1 & 0,32 & 0,23 & 0,33 & 0,48 & 0,33 & 0,21 & 0,36 & 0,35 & 0,42 & 0,41 & 0,29 \\
\hline 2 & $\mathbf{1 , 7 4}$ & $\mathbf{1 , 4 9}$ & $\mathbf{1 , 8 5}$ & $\mathbf{1 , 3 9}$ & $\mathbf{1 , 2 7}$ & 0,97 & 0,85 & 0,77 & $\mathbf{1 , 1 8}$ & $\mathbf{1 , 3 3}$ & $\mathbf{1 , 2 7}$ \\
\hline 3 & $\mathbf{5 , 3 8}$ & $\mathbf{5 , 5 7}$ & $\mathbf{4 , 2 7}$ & $\mathbf{4 , 8 7}$ & $\mathbf{5 , 1 6}$ & $\mathbf{5 , 2 4}$ & $\mathbf{7 , 7 1}$ & $\mathbf{6 , 1 8}$ & $\mathbf{7 , 0 4}$ & $\mathbf{5 , 2 5}$ & $\mathbf{4 , 5 1}$ \\
\hline 4 & $\mathbf{1 , 3 1}$ & $\mathbf{1 , 2 0}$ & $\mathbf{1 , 7 6}$ & $\mathbf{1 , 8 2}$ & $\mathbf{1 , 4 6}$ & $\mathbf{1 , 3 1}$ & $\mathbf{1 , 3 8}$ & $\mathbf{1 , 3 8}$ & $\mathbf{1 , 3 7}$ & $\mathbf{1 , 7 1}$ & $\mathbf{1 , 2 4}$ \\
\hline 5 & 0,20 & 0,19 & 0,23 & 0,39 & 0,26 & 0,40 & 0,22 & 0,16 & 0,20 & 0,20 & 0,16 \\
\hline 6 & 0,47 & 0,46 & 0,50 & 0,74 & 0,92 & 0,58 & 0,58 & 0,50 & 0,51 & 0,69 & 0,64 \\
\hline 7 & 0,00 & 0,00 & 0,00 & 0,00 & 0,00 & 0,00 & 0,00 & 0,00 & 0,00 & 0,00 & 0,00 \\
\hline 8 & $\mathbf{1 , 1 5}$ & 0,89 & $\mathbf{1 , 1 3}$ & $\mathbf{1 , 1 2}$ & 0,60 & 0,63 & 0,82 & 0,66 & $\mathbf{1 , 0 5}$ & $\mathbf{1 , 2 9}$ & $\mathbf{1 , 0 2}$ \\
\hline 9 & 0,95 & 0,75 & 0,82 & 0,47 & 0,29 & $\mathbf{2 , 4 9}$ & $\mathbf{1 , 3 3}$ & $\mathbf{3 , 1 6}$ & $\mathbf{2 , 6 7}$ & $\mathbf{3 , 4 5}$ & $\mathbf{4 , 5 0}$ \\
\hline
\end{tabular}

Źródło: opracowanie własne na podstawie Sistema gráfico de comercio internacional, https:// sgo-win12-we-e1.cepal.org/dcii/sigci/sigci.html; International Trade and Market Access Data, www.wto.org/english/res e/statis_e/statis bis e.htm?solution=WTO\&path=/Dashboards/MAPS\&file=Map.wcdf\&bookmarkState $=\{\% 22 \mathrm{impl} \% 22: \% 22$ client $\% 22, \% 22$ params $\% 22:\{\% 22$ langParam\%22:\%22en $\% 22\}$ \} (data dostępu: 10.04.2019).

Ponadto odnotowano przewage w segmentach drugim (surowce z wył. paliw mineralnych) w latach 2007-2011 oraz dziewiątym (pozostałe materiały niesklasyfikowane) w latach 2012-2017. Wskaźnik RCA oscylował powyżej 1 także w przypadku segmentu ósmego (pozostałe wyroby przemysłowe) w latach 2007 , 2009, 2010.

\section{Podsumowanie}

Międzynarodowa wymiana towarowa CAN z Mercosur w latach 2007-2017 istotnie się zmniejszyła. W 2017 r. odnotowano spadek eksportu w stosunku do 2007 r. o $32,97 \%$, a importu - o 7,92\% (por. Tabela 1). Za osłabienie intensywności wymiany towarowej pomiędzy omawianymi ugrupowaniami gospodarczymi odpowiedzialna jest w głównej mierze Wenezuela, która w każdym z segmentów klasyfikacji SITC (w przypadku zarówno eksportu, jak i importu) odnotowała znaczne zmniejszenie wolumenu wymiany towarowej z CAN, często niemal stuprocentowe (por. Tabele 2-3). Jest to wynikiem trawiącego ten kraj poważnego kryzysu nie tylko finansowo-ekonomicznego, lecz również społecznego i politycznego. W badanym okresie CAN tylko w przypadku wymiany towarowej opartej na dobrach zaklasyfikowanych do segmentów trzeciego (paliwa mineralne, smary, podobne materiały) oraz drugiego (surowce z wył. paliw mineralnych) osiągnęło dodatnie saldo bilansu obrotów towarowych (por. Wykres 1). 
Badanie przy użyciu wskaźnika RCA pokazało, że Kolumbia, Peru (z wyjątkami), Ekwador i Boliwia są silnie konkurencyjne względem Mercosur w przypadku segmentu trzeciego (paliwa mineralne, smary, podobne materiały) klasyfikacji SITC, a Peru i Boliwia (z wyjątkami) również w przypadku segmentu drugiego (surowce z wył. paliw mineralnych) (por. Tabele 4-8). Kopaliny zaklasyfikowane do segmentu trzeciego mają najwyższy udział w strukturze eksportu CAN do Mercosur (por. Tabela 2). Tym samym można stwierdzić, że dobra handlowe, w przypadku których CAN uzyskał silną przewagę komparatywną nad Mercosur, są głównym elementem międzynarodowej wymiany towarowej CAN, co świadczy o dużym znaczeniu towarów przemysłu wydobywczego dla gospodarek narodowych należących do CAN.

\section{Bibliografia}

CAN (2005), Decisión 613, www.comunidadandina.org/Documentos.aspx?Gru$\mathrm{Doc}=07$ (data dostępu: 10 kwietnia 2019).

CAN (2014), Compendio de normas de la Comunidad Andina: acuerdo de Cartagena, www.comunidadandina.org/StaticFiles/201452393622COMPENDIODENORMAS-ACUERDODECARTAGENA.pdf (data dostępu: 10 kwietnia 2019).

CEPAL (2019), Sistema gráfico de comercio internacional, https://sgo-win12-we-e1.cepal.org/dcii/sigci/sigci.html (data dostępu: $10 \mathrm{kwietnia} 2019$ ).

INGEMMET (2018), Estimación del potencial minero metálico del Perú y su contribución económica al estado, acumulado al 2050, www.ingemmet.gob.pe/documents/73138/836906/LIBRO+POTENCIAL+MINERO+2018+23-05-2018. pdf (data dostępu: 10 kwietnia 2019).

Jaszczyński M. (2016), Znaczenie handlu zagranicznego w rozwoju gospodarczym, „Zeszyty Naukowe PWSZ w Płocku”, nr 23.

Mercosur (1991), Tratado de Asunción para la constitución de un Mercado Común, www.mercosur.int/documentos-y-normativa/textos-fundacionales (data dostępu: 10 kwietnia 2019).

Mercosur (1996), Acuerdo de complementación económica $N 35$ celebrado entre los gobiernos de los estados partes del Mercosur y el Gobierno de la Republica de Chile, www2.aladi.org/biblioteca/publicaciones/aladi/acuerdos/ace/ es/ace35/web/ACE_035_Acuerdo.pdf (data dostępu: 10 kwietnia 2019).

Mercosur (2006), Protocolo de adhesión de la República Bolivariana de Venezuela al Mercosur, www.mercosur.int/documento/protocolo-adhesion-venezuela-mercosur/ (data dostępu: 10 kwietnia 2019). 
Mercosur (2015), Acuerdo marco de asociación entre el Mercosur y la República Cooperativa de Guyana, www.itamaraty.gov.br/images/notas_a_imprensa/20150717-Guiana-es.pdf (data dostępu: 10 kwietnia 2019).

Mercosur (2015), Acuerdo marco de asociación entre el Mercosur y Suriname, http://www.sice.oas.org/Trade/MRCSRS/Decisions/dec1013_s.pdf (data dostępu: 10 kwietnia 2019).

Mercosur (2015), Protocolo de adhesión del Estado Plurinacional de Bolivia al Mercosur, www.mercosur.int/documento/protocolo-adhesion-bolivia-mercosur (data dostępu: 10 kwietnia 2019).

WTO (2019), International trade and market access data, www.wto.org/english/ res_e/statis_e/statis_bis_e.htm?solution=WTO\&path=/Dashboards/MAPS\&file=Map.wcdf\&bookmarkState $=\{\% 22 \mathrm{impl} \% 22: \% 22$ client $\% 22, \% 22 \mathrm{pa}-$ rams\%22:\{\%22langParam\%22:\%22en\%22\}\} (data dostępu: 10 kwietnia 2019).

Zielińska-Głębocka A. (2012), Współczesna gospodarka światowa. Przemiany, innowacje, kryzysy, rozwiazania regionalne. Warszawa: Wolters Kluwers Polska.

\section{Streszczenie}

Celem artykułu jest określenie przewag komparatywnych w handlu towarowym czterech krajów ugrupowania CAN nad pięcioma krajami ugrupowania Mercosur w latach 2007-2017. W tym celu zastosowano wskaźnik ujawnionych przewag komparatywnych Balassy oraz klasyfikację towarów SITC (standard international trade classification). Badanie poprzedzono omówieniem międzynarodowych obrotów towarowych CAN z Mercosur.

Przeprowadzone badanie ujawniło przewagę komparatywną CAN w następujących segmentach klasyfikacji towarowej SITC: trzecim (surowce mineralne, smary i podobne materiały), ósmym (inne wyroby przemysłowe) oraz dziewiątym (inne wyroby niesklasyfikowane). Szczególnie wysoką wartość RCA w latach 2007-2017 odnotowano w przypadku segmentu trzeciego. Świadczy to o dużym znaczeniu towarów przemysłu wydobywczego dla gospodarek narodowych należących do CAN.

Słowa kluczowe: międzynarodowy handel towarami, ujawniona przewaga komparatywna, CAN, Mercosur 


\section{Summary}

Comparative advantage in the countries of the Andean Community - CAN - in the international trade of goods with Mercosur

The aim of the article is to identify comparative advantage in the trade of goods in the countries of the Andean Community (CAN; four countries) over the Mercosur group (five countries) in the years 2007-2017. For this purpose, the Balassa index of revealed comparative advantages (RCA) was used along with the Standard International Trade Classification (SITC) of goods. The study is preceded by a presentation and discussion of CAN's international trade of goods with Mercosur. On the basis of the study, it may be stated that the RCA can be found in sections three (mineral fuels, lubricants, and related products), eight (other industrial products), and nine (other unclassified goods) of SITC. Between 2007-2017, section three had a particularly high RCA value, which proves the great importance of mining goods for the national economies belonging to CAN.

Keywords: international trade of goods, revealed comparative advantage, CAN, Mercosur

JEL: F14, N76 